\title{
AC 2009-1863: EVALUATING THE EFFECTIVENESS AND USE OF CYBER-LEARNING ENVIRONMENTS IN ENGINEERING EDUCATION: A QUALITATIVE ANALYSIS
}

\section{Krishna Madhavan, Purdue University}

Dr. Krishna P.C. Madhavan is an Assistant Professor at Clemson University with a joint appointment in the Department of Engineering and Science Education and the School of Computing. Before his appointment at Clemson, he served as a Research Scientist in the Science Gateways Group at the Rosen Center for Advanced Computing, Information Technology at Purdue University where he led the education and the educational technology effort for the NSF-funded Network for Computational Nanotechnology (NCN). Dr. Madhavan was the Chair of the IEEE/ACM Supercomputing Education Program 2006 and was the curriculum director for the Supercomputing Education Program 2005. In January 2008, he was awarded the NSF CAREER for work on transforming engineering education through learner-centric, adaptive cyber-tools and cyber-environments.

\section{Jacob Schroeder, Clemson University}

Dr. Schroeder is a post-doctoral researcher at Clemson University. His work focuses on cyberinfrastructure in engineering education. He holds a Ph.D. in Chemistry Education from Iowa State University.

\section{Hanjun Xian, Clemson University}

Hanjun Xian is a Ph.D student working on issues of design of cyber-environments in engineering education at Clemson University. 


\title{
Evaluating the Effectiveness and Use of Cyberlearning Environments in Engineering Education-A Qualitative Analysis
}

\begin{abstract}
Cyberlearning is playing an increasingly important role in engineering education. According to a recent National Science Foundation (NSF) report entitled Fostering Learning in the Networked World, "cyberlearning has the potential to transform education throughout a lifetime, enabling customized interaction with diverse learning materials on any topic" (p. 5). Cyberinfrastructure forms the foundation of cyberlearning and allows students to comprehend complex engineering concepts by interacting with scientific data, visualizations, remote and virtual laboratories. New cyberlearning environments have the potential to extend learning from traditional classrooms and physical laboratories to include informal environments such as social networks and virtual spaces. Despite these significant advances, a larger theoretical framework of learning that includes cyberinfrastructure at its very core has not yet evolved.

The purpose of this research is to provide a synthesis of the fundamental characteristics of cyberlearning environments that are being created to facilitate student learning within engineering disciplines. Furthermore, we examine in-depth how educators are defining cyberlearning within the context of learning theories in general, and engineering education in particular.
\end{abstract}

Our methodology focuses on a qualitative analysis of articles in the engineering education literature drawn from The Journal of Engineering Education spanning the past 10 years. Four broad criteria guided the selection and analyses of the articles:

(1) Content: What major types of content for cyberlearning environments are being created focused particularly on engineering education? For example, the NSF identifies various categories of content for cyberlearning environments such as interactive online courses, intelligent tutors, virtual and remote laboratories, and serious games.

(2) Pedagogy: How are these cyberlearning environments being incorporated in the classroom to promote learning? For example, several educators have reported using the learning technology to supplement a traditional lecture or course. Others have replaced the traditional classroom altogether.

(3) Audience: Who is the primary audience for the cyberlearning environments? For example, these environments can be created for both students and faculty to promote distance learning - allowing better access for participants from remote locations lacking high-cost instrumentation and facilities.

(4) Outcomes: What learning outcomes are being measured? Is the cyberlearning environment enhancing these outcomes? For example, specific outcomes can include student content knowledge measured by exam performance or concept inventories and student perceptions measured by course evaluations.

The results presented in this paper draw out major trends in cyberlearning within the context of engineering education over the past decade. 


\section{Introduction}

Engineering education continues to undergo rapid change, and with that change new challenges are presented. Students in engineering today need to be able to adapt to a global economy, to collaborate and communicate with members of geographically distributed teams, and to become lifelong learners continually updating their knowledge ${ }^{1-6}$. These challenges are by no means the only ones facing students or the educators that train them. The emergence of advanced high-end computing and networking technologies have made it nearly impossible for any practicing engineer to work in isolation. Simply put, "tomorrow's graduate will need to collaboratively contribute expertise across multiple perspectives in an emerging global economy that is fueled by rapid innovation and marked by an astonishing pace of technological breakthroughs"7.

The World Wide Web has revolutionized the way people access information and has provided multiple new ways for people to communicate with each other. The amount of accessible information on the Web allows learning to be viewed as an ongoing exercise that can be experienced in a variety of settings, both formal and informal. The classroom can now be broadcast online to anyone, anywhere, anytime ${ }^{8}$. Furthermore, educational infrastructures can be created that allow engineering educators to create educational innovations and share them with others no matter where they are located ${ }^{9}$. For many students today, it has always been this way.

Today's students have been referred to as the Net Generation, having never known life without the Internet and not being able to imagine life without it $^{10,11}$. Both EDUCAUSE and the PEW Research Center have produced numerous reports documenting the increasing amount of time both students and the general public spend online ${ }^{12,13}$. Other studies have shown that students today are very much interested in the latest forms of technology, preferring interactivity in the classroom, problem-based experiences including feedback, and online software ${ }^{11}$. To meet these interests, many educators have been inventing or adapting clever and effective computer-based tools including simulation and modeling software, digital libraries, and visualization games. In an extensive review of the literature, covering over 2200 studies involving instructional technology, Kadiyala and Crynes provide substantial evidence that information technologies can enhance learning so long as the pedagogy is sound, and when there is a good match of technology, techniques, and objectives ${ }^{14}$.

\section{Cyberinfrastructure and Education}

The National Science Foundation (NSF) has been leading efforts to report on the implementation and evaluation of an emerging cyberinfrastructure to enhance research ${ }^{15-17}$. They use the term cyberinfrastructure to refer to an infrastructure based upon distributed computers, information and communication technologies, all of which are required for a knowledge economy. This advanced networking enables people, tools, and information to be linked in ways that reduce barriers of location, time, institution, and discipline. In their most recent report, the NSF expands the applicability of cyberinfrastructure into the classroom, defining cyberlearning as the "use of networked computing and communication technologies to enhance learning"18. According to the report:

"Cyberlearning has the potential to transform education throughout a lifetime, enabling customized interaction with diverse learning materials on any topicfrom anthropology to biochemistry to civil engineering to zoology. Learning does 
not stop with $\mathrm{K}-12$ or higher education; cyberlearning supports continuous education at any age." (p. 5)

In this paper, we examine cyberlearning as a pedagogical paradigm seen through the lens of papers published in the Journal of Engineering Education. In the following sections, we highlight our methodology and identify larger cyberlearning trends within the field of engineering education.

\section{Methodology}

To understand where the engineering education community is with regard to the cyberlearning vision of the NSF, we have summarized studies covering the use of cyberlearning technologies reported in the Journal of Engineering Education from January 1999 to October 2008. During this time 483 research articles have been published. Analyzing keywords, abstracts, titles, and general themes of each article, we have identified 86 articles that focus on the development, implementation, or the assessment of the use of cyberlearning technologies or environments. A variety of different technologies were presented, and in some cases were bundled with others in an interactive suite. For articles in which this was the case, we attempted to determine if the article focused on any particular portion of the bundle. In an effort to categorize articles according to common themes and foci, we analyzed the technology reported, how it was delivered, and whether it was used in combination with other forms of instructional technology. Using these broad criteria, we have identified five categories of cyberlearning technologies: (1) web-based delivery mechanisms; (2) adaptive or intelligent tutorials; (3) interactive simulations; (4) remote or virtual laboratories; and (5) virtual games. While these categories provide a general classification, they should in no way be interpreted as definitive.

A common theme shared by all of the technologies discussed is that they are web-based learning environments. Web-based delivery mechanisms were generally used to (1) promote collaboration and communication among geographically distributed participants; (2) broadcast video and audio from a traditional classroom lecture; and (3) serve as a repository of classroom materials such as the course syllabus, announcements, and homework problems. Adaptive and intelligent tutoring systems were developed to help students learn material outside of traditional class times. Simulations served to represent real-world phenomena that may be too small, fast, or complex for students to explore in typical classrooms. They were interactive, allowing students to input different variables and to visually observe the result of their inputs. In some cases, they were linked to large databases.

Each article within each category was subjected to a four-tiered analysis that focused on content, pedagogy, audience, and assessment in an effort to identify common trends. The content analysis was performed to further explore the types of learning environments that have been developed and in what context they are being used within engineering education. Articles were then analyzed to determine the pedagogical approaches used. Specifically, how did the participants interact with the learning environment? How was the learning environment incorporated into the course content? Three common pedagogical trends emerged:

(1) Supplement: The cyberlearning environment served as an enhancement in conjunction with traditional learning activities throughout the entire duration of the course. 
(2) Replacement: The cyberlearning environment served as the primary means of instruction.

(3) Combination: The cyberlearning environment was used as a treatment in experimental studies. Therefore, a significant number of participants may not have used the cyberlearning environment despite it being part of a course.

The next part of our analysis was to determine the primary audience for each of the studies. Here we considered the demographics and characteristics of the experimental and control groups. The final part of our analysis focused on the assessment methods that were reported in the papers. For the purposes of this study, only those research articles that reported assessment results were included in the analysis.

\section{Analysis}

\subsection{Web-based Delivery Mechanisms}

Table 1: Collaboration and Communication

\begin{tabular}{|c|c|c|c|c|c|}
\hline First Author & Content & Pedagogy & Audience & Assessment & Results \\
\hline Tseng, K-H. $^{19}$ & Online platform & $\begin{array}{l}\text { Replaced } \\
\text { (3 days) }\end{array}$ & $\begin{array}{l}\text { IT experts, } \\
\text { academics, } \\
\text { instructors (13) }\end{array}$ & Survey & $\begin{array}{l}\text { Significantly high } \\
\text { ratings for } \\
\text { effectiveness }\end{array}$ \\
\hline Whitman, L. ${ }^{20}$ & Blackboard $^{\mathrm{TM}}$ & $\begin{array}{l}\text { Replaced } \\
(1 \text { term })\end{array}$ & $\begin{array}{l}\text { Graduate students } \\
\text { (18) }\end{array}$ & $\begin{array}{l}\text { Survey \& } \\
\text { performance } \\
\text { data (grades) }\end{array}$ & $\begin{array}{l}\text { Control group more } \\
\text { satisfied, no } \\
\text { performance } \\
\text { differences }\end{array}$ \\
\hline Kirschman, J. ${ }^{21}$ & NetMeeting & $\begin{array}{l}\text { Replaced } \\
\text { (3 tasks) }\end{array}$ & $\begin{array}{l}60 \text { undergraduate } \\
\text { and graduate } \\
\text { students ( } 5 \\
\text { courses) }\end{array}$ & $\begin{array}{l}\text { Survey \& } \\
\text { performance } \\
\text { data ( } 3 \text { tasks) }\end{array}$ & $\begin{array}{l}\text { Control group } \\
\text { performed higher } 3 \\
\text { tasks, more satisfied } \\
\text { on } 2 \text { of } 3 \text { tasks }\end{array}$ \\
\hline Rutar, T. ${ }^{22}$ & $\begin{array}{l}\text { E-mail, } \\
\text { NetMeeting }\end{array}$ & $\begin{array}{l}\text { Replaced } \\
(1 \text { term })\end{array}$ & $\begin{array}{l}80 \text { University and } \\
40 \text { high school } \\
\text { students ( } 3 \\
\text { courses) }\end{array}$ & $\begin{array}{l}\text { Survey \& } \\
\text { performance } \\
\text { data }(\mathrm{HW})\end{array}$ & $\begin{array}{l}\text { Experimental group } \\
\text { gained better } \\
\text { understanding and } \\
\text { confidence }\end{array}$ \\
\hline Paterson, $\mathrm{K} .{ }^{23}$ & $\begin{array}{l}\text { Web-based } \\
\text { learning tools }\end{array}$ & $\begin{array}{l}\text { Supplement } \\
\text { (1 term) }\end{array}$ & $\begin{array}{l}83 \text { undergraduate } \\
\text { students }\end{array}$ & Survey & Usage ratings \\
\hline Liang, $\mathrm{T}^{24}$ & Online database & $\begin{array}{l}\text { Supplement } \\
\text { (3 years) }\end{array}$ & $\begin{array}{l}45-60 \text { graduate } \\
\text { students each year }\end{array}$ & $\begin{array}{l}\text { Interviews \& } \\
\text { performance } \\
\text { data (grades) }\end{array}$ & $\begin{array}{l}\text { More data do not } \\
\text { correlate with more } \\
\text { usage; more usage } \\
\text { does not correlate with } \\
\text { performance }\end{array}$ \\
\hline
\end{tabular}

The first four articles in Table 1 focused on testing collaboration and communication among geographically distributed participants who communicated using only the Internet. Specifically, Tseng et al. ${ }^{19}$ reported that an online Nominal Group Technique (NGT) platform proved to be an effective medium for IT experts, academics, and instructors to discuss resolving educational problems based on the concept of knowledge transfer. They report significantly high ratings on a number of survey questions gauging the effectiveness of the platform. However, they do not report any results from a traditional control group. 
In three related studies ${ }^{20-22}$, group dynamics and performance between teams of students communicating over the Internet (experimental) were compared with teams of students communicating in a traditional face-to-face manner (control). Whitman et al. ${ }^{20}$ reported that student teams in the experimental group performed equally as well on a final project as student teams in the control group. But, teams in the control group indicated higher levels of satisfaction with various measures of group dynamics. Kirschman and Greenstein ${ }^{21}$ reported higher levels of satisfaction on two of three tasks among members of the control group. Also, they reported higher quality ratings on all three tasks for the control group. Rutar and Mason ${ }^{22}$ reported that student teams in the experimental group felt they had a better understanding of a design problem and the design process. Students also achieved a higher final report score. In a separate study, Paterson $^{23}$ reported that students gave the lowest ratings for the educational value of an electronic discussion forum even though they were required to submit and answer questions in the forum for a portion of their overall course grade.

Liang et al. ${ }^{24}$ created an online community database that allowed students to store design information over five years. Peer teams were allowed to access information not only from the current year, but also from prior years. One of their findings was that students often re-invented information rather than going to the database to look for answers. They attributed this to the amount of time required to search through a growing database. Also, students perceived the process of re-inventing the information as an opportunity for learning. They found no correlation between the amount of use of the information in the database and the performance of the students.

A subset of web-based delivery studies presented results from experiences with distance education. Different modes of media delivery mechanisms were compared with each other and with traditional face-to-face lectures. The media involved were used primarily to broadcast a classroom lecture either synchronously or asynchronously using video and audio over the web. For clarity, we refer to students receiving a traditional face-to-face lecture as the control group and students receiving alternate modes of instruction as the experimental group. The descriptive results are displayed in Table 2.

Table 2: Traditional Lecture

\begin{tabular}{|c|c|c|c|c|c|}
\hline First Author & Content & Pedagogy & Audience & Assessment & Results \\
\hline Hailey, C. ${ }^{25}$ & $\begin{array}{l}\text { Web-based } \\
\text { lecture }\end{array}$ & $\begin{array}{l}\text { Combination } \\
\text { (several } \\
\text { different } \\
\text { studies) }\end{array}$ & $\begin{array}{l}\text { Differing numbers } \\
\text { of students over } 7 \\
\text { years }\end{array}$ & $\begin{array}{l}\text { Performance } \\
\text { data (quiz } \\
\text { scores) }\end{array}$ & $\begin{array}{l}\text { Several different } \\
\text { results depending on } \\
\text { the year of the study } \\
\text { presented }\end{array}$ \\
\hline Rutz, E. ${ }^{26}$ & $\begin{array}{l}\text { Web-based } \\
\text { lecture }\end{array}$ & Supplement & $\begin{array}{l}\text { Undergraduate } \\
\text { students over } 2 \\
\text { terms }(34 ; 24)\end{array}$ & $\begin{array}{l}\text { Survey \& } \\
\text { performance } \\
\text { data (grades) }\end{array}$ & $\begin{array}{l}\text { Scores in Web-course } \\
\text { significantly higher } \\
\text { than traditional; }\end{array}$ \\
\hline Dutton, J. ${ }^{27}$ & $\begin{array}{l}\text { Web-based } \\
\text { lecture }\end{array}$ & $\begin{array}{l}\text { Replaced (1 } \\
\text { term) }\end{array}$ & 141 students & $\begin{array}{l}\text { Performance } \\
\text { data (final } \\
\text { exam and } \\
\text { grade) }\end{array}$ & $\begin{array}{l}\text { Experimental group } \\
\text { performed } \\
\text { significantly higher; } \\
\text { more students dropped } \\
\text { the course }\end{array}$ \\
\hline Foertsch, J. ${ }^{28}$ & $\begin{array}{l}\text { Web-based } \\
\text { lecture }\end{array}$ & $\begin{array}{l}\text { Replaced (1 } \\
\text { term) }\end{array}$ & $\begin{array}{l}\text { Undergraduate } \\
\text { students }(277)\end{array}$ & Survey & $\begin{array}{l}\text { Experimental gave } \\
\text { significantly higher } \\
\text { ratings for the course }\end{array}$ \\
\hline
\end{tabular}




\begin{tabular}{|c|c|c|c|c|c|}
\hline Haag, S. ${ }^{29}$ & $\begin{array}{l}\text { Web-based } \\
\text { lecture }\end{array}$ & $\begin{array}{l}\text { Replaced (1 } \\
\text { term) }\end{array}$ & $\begin{array}{l}22 \text { graduate and } \\
\text { undergraduate } \\
\text { students }\end{array}$ & $\begin{array}{l}\text { Survey \& } \\
\text { performance } \\
\text { data (grades) }\end{array}$ & $\begin{array}{l}\text { No significant } \\
\text { performance } \\
\text { differences; } \\
\text { experimental more } \\
\text { satisfied }\end{array}$ \\
\hline Webster, T. ${ }^{30}$ & $\begin{array}{l}\text { Interactive } 2- \\
\text { way } \\
\text { video/audio }\end{array}$ & $\begin{array}{l}\text { Combination } \\
\text { ( } 1 \text { control; } 3 \\
\text { experimental } \\
\text { modules }\end{array}$ & $\begin{array}{l}19 \text { graduate } \\
\text { students over } 2 \\
\text { terms and } 2 \\
\text { locations }\end{array}$ & $\begin{array}{l}\text { Survey \& } \\
\text { Performance } \\
\text { data (grades) }\end{array}$ & $\begin{array}{l}\text { No significant } \\
\text { performance } \\
\text { differences; } \\
\text { experimental gave } \\
\text { higher course ratings }\end{array}$ \\
\hline $\begin{array}{l}\text { Thiagarajan, } \\
\text { G. }\end{array}$ & $\begin{array}{l}\text { Web-based } \\
\text { lecture }\end{array}$ & $\begin{array}{l}\text { Replaced (1 } \\
\text { term) }\end{array}$ & $\begin{array}{l}34 \text { undergraduate } \\
\text { students }\end{array}$ & $\begin{array}{l}\text { Survey \& } \\
\text { performance } \\
\text { data (exams) }\end{array}$ & $\begin{array}{l}\text { No significant } \\
\text { performance } \\
\text { differences; control } \\
\text { group gave higher } \\
\text { course ratings }\end{array}$ \\
\hline Evans, R. ${ }^{32}$ & $\begin{array}{l}\text { Web-based } \\
\text { lecture }\end{array}$ & $\begin{array}{l}\text { Replaced (1 } \\
\text { term) }\end{array}$ & $\begin{array}{l}92 \text { students in } 5 \\
\text { classes at } 2 \\
\text { locations }\end{array}$ & $\begin{array}{l}\text { Pre/post-test; } \\
\text { survey }\end{array}$ & $\begin{array}{l}\text { No significant } \\
\text { performance } \\
\text { differences; positive } \\
\text { comments }\end{array}$ \\
\hline Rafe, G. ${ }^{33}$ & $\begin{array}{l}\text { Web-based } \\
\text { lecture }\end{array}$ & Replaced & $\begin{array}{l}105 \text { graduate } \\
\text { students in } 16 \\
\text { courses over } 5 \\
\text { terms }\end{array}$ & Survey & $\begin{array}{l}\text { Positive comments, } \\
\text { but no comparison } \\
\text { between groups }\end{array}$ \\
\hline
\end{tabular}

The first three articles present results in which the experimental group achieved higher scores than the control group on various performance measures. Two studies tested the effect of a number of media delivery mechanisms on student performance. In both cases, the alternate media delivery mechanisms had no significant impact on student performance ${ }^{25,26}$. However, students viewing the lecture on the web performed significantly higher on quizzes ${ }^{25}$ or received higher overall grades ${ }^{26}$ than students in the traditional face-to-face lecture. The results based on web-based delivery mechanisms were consistent with observations by Dutton et al. ${ }^{27}$. However, the number of online students who dropped the course was significantly higher than students in the traditional lecture ${ }^{27}$.

The remaining six studies either found no significant differences in student performance or did not assess performance data. In terms of student surveys, the experimental groups in these studies reported significantly higher ratings for the web-based course on the following criteria: (1) usefulness, convenience, and value ${ }^{28}$; (2) convenience and communication ${ }^{29}$; and (3) higher overall course ratings ${ }^{30,32,33}$. However, technical problems associated with the delivery mechanism could have a negative effect on student learning. Also, students needed to be actively engaged in the class rather than passive recipients of a broadcast ${ }^{31,33}$.

A second subset of web-based delivery studies describe either using web-accessible devices in the classroom or providing course related materials on the course website. In general, the more students used online materials, the higher they scored on various performance measures. Significant results were found in studies involving the use of a classroom communication system $^{34}, \mathrm{PDAs}^{35}$, and online homework problems ${ }^{38,39}$. The use of laptops in the classroom did not have a statistically significant impact on student scores ${ }^{36}$. 
Table 3: Online Materials

\begin{tabular}{|c|c|c|c|c|c|}
\hline First Author & Content & Pedagogy & Audience & Assessment & Results \\
\hline Roselli, R. ${ }^{34}$ & $\begin{array}{l}\text { Classroom } \\
\text { communication } \\
\text { system } \\
\text { (clickers) }\end{array}$ & $\begin{array}{l}\text { Supplement } \\
\text { (1 term) }\end{array}$ & $\begin{array}{l}\text { Undergraduate } \\
\text { students (number } \\
\text { undefined) }\end{array}$ & $\begin{array}{l}\text { Survey \& } \\
\text { performance } \\
\text { data }\end{array}$ & $\begin{array}{l}\text { Significant gains on } \\
\text { final exam; positive } \\
\text { comments }\end{array}$ \\
\hline Doolen, $\mathrm{T}^{35}$ & $\begin{array}{l}\text { Personal digital } \\
\text { assistants (Web- } \\
\text { accessible) }\end{array}$ & $\begin{array}{l}\text { Supplement } \\
\text { (half term) }\end{array}$ & $\begin{array}{l}50 \text { undergraduate } \\
\text { students }\end{array}$ & $\begin{array}{l}\text { Survey \& } \\
\text { performance } \\
\text { data (mid-term } \\
\text { exam) }\end{array}$ & $\begin{array}{l}\text { Experimental group } \\
\text { performed } \\
\text { significantly higher on } \\
\text { exam; positive } \\
\text { attitutes }\end{array}$ \\
\hline Kolar, R.L. ${ }^{36}$ & $\begin{array}{l}\text { Laptops in class } \\
\text { (Web- } \\
\text { accessible) }\end{array}$ & $\begin{array}{l}\text { Supplement } \\
(2 \text { terms })\end{array}$ & $\begin{array}{l}\text { Undergraduate } \\
\text { students over } 2 \\
\text { terms }(11 ; 12)\end{array}$ & $\begin{array}{l}\text { Survey \& } \\
\text { Performance } \\
\text { data (grades) }\end{array}$ & $\begin{array}{l}\text { No significant } \\
\text { performance } \\
\text { differences; positive } \\
\text { student comments }\end{array}$ \\
\hline Newman, D.J. ${ }^{37}$ & $\begin{array}{l}\text { Online } \\
\text { supplemental } \\
\text { materials }\end{array}$ & $\begin{array}{l}\text { Supplement } \\
(1 \text { term })\end{array}$ & $\begin{array}{l}31 \text { undergraduate } \\
\text { students }\end{array}$ & Survey & $\begin{array}{l}\text { Significantly higher } \\
\text { ratings }\end{array}$ \\
\hline Taraban, R. ${ }^{38}$ & $\begin{array}{l}\text { Online } \\
\text { homework with } \\
\text { feedback }\end{array}$ & $\begin{array}{l}\text { Supplement } \\
(1 \text { term })\end{array}$ & $\begin{array}{l}\text { Undergraduate } \\
\text { students at } 2 \\
\text { locations }(29 ; 72)\end{array}$ & $\begin{array}{l}\text { Performance } \\
\text { data } \\
\text { (homework, } \\
\text { exams) }\end{array}$ & $\begin{array}{l}\text { Completing online } \\
\text { homework is highly } \\
\text { correlated to grades }\end{array}$ \\
\hline Taraban, $\mathrm{R}^{39}$ & $\begin{array}{l}\text { Online learning } \\
\text { resources }\end{array}$ & $\begin{array}{l}\text { Supplement } \\
\text { (1 week) }\end{array}$ & $\begin{array}{l}\text { Undergraduate } \\
\text { students at } 2 \\
\text { locations (147; } \\
64)\end{array}$ & $\begin{array}{l}\text { Usage } \\
\text { statistics }\end{array}$ & $\begin{array}{l}\text { Usage of materials is } \\
\text { correlated with } \\
\text { academic performance }\end{array}$ \\
\hline Marks, $\mathrm{B}^{40}$ & $\begin{array}{l}\text { Online learning } \\
\text { resources }\end{array}$ & $\begin{array}{l}\text { Supplement } \\
\text { (4 terms) }\end{array}$ & $\begin{array}{l}\text { Undergraduate } \\
\text { students from } 3 \\
\text { classes at } 2 \\
\text { locations }(11,20 ; \\
29,17)\end{array}$ & Survey & $\begin{array}{l}\text { Students more likely } \\
\text { to read materials }\end{array}$ \\
\hline
\end{tabular}

Students were more likely to read course materials to prepare for an online readiness assessment quiz $^{40}$. A separate study ${ }^{37}$ showed that students were more comfortable working on technical problems with no clear answers. Also, students were more at ease designing and building a device from an assortment of given parts. In all of the above studies, students gave positive comments and ratings to their respective courses indicating that the integration of the Internet gave them more access to course materials as needed.

\subsection{Tutorials}

In this section, we present articles that focus on the use of web-based learning systems that incorporate tutorials with built-in feedback mechanisms. These feedback mechanisms were designed to provide students help based on their responses or progress within the tutorial. In general, implementing any of these learning systems had no negative impact on student learning. However, considerable variability existed in how each of these systems were implemented and assessed for their effectiveness. Generally, on attitude surveys, students gave positive ratings and comments for the course as well as for the effectiveness of learning system. In only one case did students report that they would prefer the traditional learning environment ${ }^{46}$. 
Table 4: Adaptive and Online Tutorials

\begin{tabular}{|c|c|c|c|c|c|}
\hline First Author & Content & Pedagogy & Audience & Assessment & Results \\
\hline Roselli, $\mathrm{R}^{41}$ & $\begin{array}{l}\text { STAR Legacy } \\
\text { Cycle }\end{array}$ & $\begin{array}{l}\text { Supplement } \\
(10-13 \\
\text { modules })\end{array}$ & $\begin{array}{l}\text { Undergraduate } \\
\text { students over } 3 \\
\text { terms ( } \sim 50 \text { each } \\
\text { term) }\end{array}$ & $\begin{array}{l}\text { Survey \& } \\
\text { performance } \\
\text { data (final } \\
\text { exam) }\end{array}$ & $\begin{array}{l}\text { No significant } \\
\text { performance } \\
\text { differences; } \\
\text { experimental group } \\
\text { gave higher ratings }\end{array}$ \\
\hline Rayne, $\mathrm{K}^{42}$ & $\begin{array}{l}\text { STAR Legacy } \\
\text { Cycle }\end{array}$ & Supplement & $\begin{array}{l}109 \text { students at } 3 \\
\text { schools over } 3 \\
\text { days }\end{array}$ & $\begin{array}{l}\text { Pre/post-test ( } 3 \\
\text { questions) }\end{array}$ & $\begin{array}{l}\text { No significant } \\
\text { performance } \\
\text { differences }\end{array}$ \\
\hline Pandy, $\mathrm{M}^{43}$ & $\begin{array}{l}\text { STAR Legacy } \\
\text { Cycle }\end{array}$ & $\begin{array}{l}\text { Replaced (1 } \\
\text { challenge } \\
\text { for } 2 \text { class } \\
\text { periods) }\end{array}$ & $\begin{array}{l}13 \text { undergraduate } \\
\text { students }\end{array}$ & $\begin{array}{l}\text { Pre/post-test ( } 3 \\
\text { questions) }\end{array}$ & $\begin{array}{l}\text { Significant gains in } 2 \\
\text { areas }\end{array}$ \\
\hline Greenberg, J. ${ }^{44}$ & $\begin{array}{l}\text { STAR Legacy } \\
\text { Cycle }\end{array}$ & $\begin{array}{l}\text { Supplement } \\
\text { (1 module) }\end{array}$ & $\begin{array}{l}22 \text { undergraduate } \\
\text { students }\end{array}$ & $\begin{array}{l}\text { Survey \& } \\
\text { performance } \\
\text { data (scoring } \\
\text { rubric) }\end{array}$ & $\begin{array}{l}\text { Experimental group } \\
\text { demonstrated better } \\
\text { understanding; } \\
\text { positive comments }\end{array}$ \\
\hline $\begin{array}{l}\text { Hadjileontiadou, } \\
\mathrm{S}^{45}\end{array}$ & $\begin{array}{l}\text { Lin2k Web- } \\
\text { based tutorial }\end{array}$ & $\begin{array}{l}\text { Supplement } \\
\text { (full term) }\end{array}$ & 84 undergraduates & Survey & $\begin{array}{l}\text { Positive comments } \\
\text { and more } \\
\text { collaboration }\end{array}$ \\
\hline Nguyen, J. ${ }^{46}$ & $\begin{array}{l}\text { Web-based } \\
\text { tutorial }\end{array}$ & $\begin{array}{l}\text { Replaced (1 } \\
\text { module, } 2 \\
\text { weeks) }\end{array}$ & $\begin{array}{l}43 \text { undergraduate } \\
\text { students }\end{array}$ & $\begin{array}{l}\text { Pre/post-test \& } \\
\text { survey }\end{array}$ & $\begin{array}{l}\text { No significant } \\
\text { performance } \\
\text { differences; students } \\
\text { preferred traditional }\end{array}$ \\
\hline Masten, $\mathrm{S}^{47}$ & CAPA & $\begin{array}{l}\text { Supplement } \\
\text { (full term) }\end{array}$ & $\begin{array}{l}\text { Undergraduate } \\
\text { students over } 3 \\
\text { terms ( } 275 \text { total })\end{array}$ & $\begin{array}{l}\text { Survey \& } \\
\text { performance } \\
\text { data (grades) }\end{array}$ & Higher grades \\
\hline Kashy, D. ${ }^{48}$ & CAPA & $\begin{array}{l}\text { Supplement } \\
\text { (full term) }\end{array}$ & $\begin{array}{l}\text { Undergraduate } \\
\text { students over } 2 \\
\text { terms ( }>500 \text { total })\end{array}$ & $\begin{array}{l}\text { Performance } \\
\text { data (grades) }\end{array}$ & Higher grades \\
\hline Dorneich, M. ${ }^{49}$ & $\begin{array}{l}\text { Web-based } \\
\text { tutorial }\end{array}$ & $\begin{array}{l}\text { Supplement } \\
\text { (1 module) }\end{array}$ & $\begin{array}{l}4 \text { undergraduate } \\
\text { students }\end{array}$ & Survey & Positive ratings \\
\hline $\begin{array}{l}\text { Kortemeyer, } \\
\text { G. }^{50}\end{array}$ & LectureOnline & Supplement & $\begin{array}{l}\text { Undergraduate } \\
\text { students over } 14 \\
\text { different courses }\end{array}$ & $\begin{array}{l}\text { Performance } \\
\text { data }\end{array}$ & $\begin{array}{l}\text { No significant } \\
\text { differences }\end{array}$ \\
\hline
\end{tabular}

The STAR Legacy cycle was discussed in four of the articles. Although no overall significant differences on performance measures were reported in two studies ${ }^{41,42}$, another found an increase in students' conceptual knowledge and their ability to transfer knowledge to new situations ${ }^{43}$. A fourth study found that the STAR Legacy cycle enabled students to demonstrate better understanding compared to traditional methods of studying the materia ${ }^{44}$. Similarly, the CAPA system was discussed in two articles. In both cases, higher student grades were observed ${ }^{47,48}$. The LectureOnline ${ }^{\circledR}$ system was studied over 14 different courses. No significant performance differences were observed between students who used this system and those who did not ${ }^{50}$. A separate study evaluated the use of a web-based tutorial to teach concepts of a spectrometer. The assessment included the ratings on only one specific feature of the tutorial from four students (out of 300$)^{49}$. 
Intelligent tutoring systems have the ability to teach a given subject, detect student errors, try to figure out where and how the student made an error, and correct flaws in the student's logic ${ }^{51}$. Positive results were reported in both cases where intelligent tutoring systems were used. Specifically, there was a significant correlation between the amount of time students spent using the system and their performance ${ }^{52}$. However, student performance scores were not reported for both groups. In a separate study students achieved significant gains on their post-test performance $^{53}$. This performance, however, is not compared to the performance of a control group. Students in both studies reported the instructional materials were easy to use and commented positively about their learning experiences. These results are summarized in Table 5.

Table 5: Intelligent Tutoring Systems

\begin{tabular}{|c|c|c|c|c|c|}
\hline First Author & Content & Pedagogy & Audience & Assessment & Results \\
\hline Dearholt, D. ${ }^{52}$ & Pathfinder & $\begin{array}{l}\text { Replaced (6 } \\
\text { weeks) }\end{array}$ & $\begin{array}{l}31 \text { undergraduate } \\
\text { students }\end{array}$ & Survey & $\begin{array}{l}\text { Strong correlation } \\
\text { between use of the } \\
\text { system and } \\
\text { achievement }\end{array}$ \\
\hline Hsieh, S-J. ${ }^{53}$ & $\begin{array}{l}\text { Intelligent } \\
\text { tutoring }\end{array}$ & $\begin{array}{l}\text { Supplement } \\
(2 \text { terms })\end{array}$ & $\begin{array}{l}\text { Undergraduates } \\
\text { over } 2 \text { terms }(90 \text {; } \\
38)\end{array}$ & $\begin{array}{l}\text { Pre/post-test \& } \\
\text { survey }\end{array}$ & $\begin{array}{l}\text { Significant gains on } \\
\text { post test }\end{array}$ \\
\hline
\end{tabular}

\subsection{Simulations and Serious Games}

Students who used web-based simulations rated them positively. Student learning also improved after using web-based simulations as measured by gains in post-test scores ${ }^{58}$. Some of these learning gains were significant ${ }^{55,56}$. However, McKenna and Agogino ${ }^{56}$ reported that students who did not have access to the web-based simulation performed just as well as those who had access. Although the use of simulations can lead to a decrease in the performance gap among some student demographics, they can also lead to an increasing performance gap among others ${ }^{54}$. While these results are mixed, in all cases, the authors of each of the studies indicated that students appeared more confident and engaged in the classroom. Evidence for this was seen in an Internet-based bridge design contest, which showed nearly a $20 \%$ increase in participants from $2002-2003^{57}$. Fifty percent of the students who participated in the bridge design contest reported an increased interest in engineering.

Table 6: Web-based Simulation

\begin{tabular}{|c|c|c|c|c|c|}
\hline First Author & Content & Pedagogy & Audience & Assessment & Results \\
\hline Cantrell, $\mathrm{P}^{54}$ & $\begin{array}{l}\text { Web-based } \\
\text { simulation }\end{array}$ & $\begin{array}{l}\text { Supplement } \\
\text { (3 modules) }\end{array}$ & $\begin{array}{l}8 \text { teachers and } \\
434 \text { middle school } \\
\text { students }\end{array}$ & $\begin{array}{l}\text { Survey \& } \\
\text { performance } \\
\text { data (tests) }\end{array}$ & Mixed results \\
\hline Diefes-Dux, H. ${ }^{55}$ & $\begin{array}{l}\text { Web-based } \\
\text { simulation }\end{array}$ & $\begin{array}{l}\text { Supplement } \\
\text { (7 modules) }\end{array}$ & $\begin{array}{l}12 \text { undergraduate } \\
\text { students }\end{array}$ & $\begin{array}{l}\text { Survey \& } \\
\text { performance } \\
\text { data } \\
\text { (homework) }\end{array}$ & $\begin{array}{l}\text { Students were } \\
\text { successful; positive } \\
\text { ratings and comments }\end{array}$ \\
\hline McKenna, A. ${ }^{56}$ & $\begin{array}{l}\text { Web-based } \\
\text { simulation }\end{array}$ & $\begin{array}{l}\text { Combination } \\
\text { (3 different } \\
\text { treatments) }\end{array}$ & $\begin{array}{l}\text { High school and } \\
\text { middle school } \\
\text { students at two } \\
\text { locations }(24 ; 24)\end{array}$ & $\begin{array}{l}\text { Pre/post-test } \\
\text { performance }\end{array}$ & $\begin{array}{l}\text { All groups showed } \\
\text { significant gains; no } \\
\text { difference between } \\
\text { groups }\end{array}$ \\
\hline
\end{tabular}




\begin{tabular}{llllll} 
Ressler, S. $^{57}$ & $\begin{array}{l}\text { Web-based } \\
\text { simulation }\end{array}$ & $\begin{array}{l}\text { Replaced } \\
\text { (contest) }\end{array}$ & $\begin{array}{l}\sim 30,000 \text { middle } \\
\text { and high school } \\
\text { students }\end{array}$ & Survey & $\begin{array}{l}\text { Positive ratings and } \\
\text { comments; increasing } \\
\text { usage }\end{array}$ \\
Mohtar, R. ${ }^{58}$ & $\begin{array}{l}\text { Web-based } \\
\text { simulation }\end{array}$ & $\begin{array}{l}\text { Supplement } \\
(2 \text { modules) }\end{array}$ & $\begin{array}{l}15 \text { undergraduate } \\
\text { students }\end{array}$ & $\begin{array}{l}\text { Pre/post test \& } \\
\text { survey }\end{array}$ & $\begin{array}{l}\text { Gains on post-test but } \\
\text { not significant; } \\
\text { positive comments } \\
\text { and ratings }\end{array}$ \\
\hline
\end{tabular}

The two studies in Table 7 report results of using serious games to enhance learning ${ }^{59,60}$. Both studies compared results with a control group that participated in the respective course during a different term when the games were not available. Results in the second study ${ }^{60}$ were limited because the assessment instrument only measured student performance on one question. However, the students in the study collectively gave positive rankings on the end-of-term evaluation.

Table 7: Web-based Games

\begin{tabular}{llllll}
\hline First Author & Content & Pedagogy & Audience & Assessment & Results \\
\hline Panetta, K. $^{59}$ & $\begin{array}{l}\text { TEAMThink } \\
\text { quiz making } \\
\text { game }\end{array}$ & $\begin{array}{l}\text { Supplement } \\
(2 \text { terms) }\end{array}$ & $\begin{array}{l}140 \text { students in } 2 \\
\text { courses }\end{array}$ & $\begin{array}{l}\text { Performance } \\
\text { data (exams) }\end{array}$ & Increased exam scores \\
Crown, S. $^{60}$ & $\begin{array}{l}\text { Web-based } \\
\text { visualization } \\
\text { games }\end{array}$ & $\begin{array}{l}\text { Supplement } \\
(7 \text { terms) }\end{array}$ & $\begin{array}{l}\text { Undergraduate } \\
\text { students } \\
\text { (undefined } \\
\text { number) }\end{array}$ & $\begin{array}{l}\text { Survey \& } \\
\text { performance } \\
\text { data (1 } \\
\text { question) }\end{array}$ & $\begin{array}{l}\text { Increased scores; } \\
\text { positive comments }\end{array}$ \\
\hline
\end{tabular}

\subsection{Laboratories}

We define remote laboratories as a network system wherein participants do not interact physically with instruments. Control of the instruments is achieved via a series of remotely issued commands. Virtual laboratories relied on the use of web-based simulations to perform experiments. Laboratory experiments hold a dominant place in most undergraduate engineering curricula serving as an environment for hands-on learning. The articles in Table 8 present results describing experiences with virtual and remote laboratories.

Table 8: Virtual and Remote Laboratories

\begin{tabular}{llllll}
\hline First Author & Content & Pedagogy & Audience & Assessment & Results \\
\hline Alexander, D. & $\begin{array}{l}\text { Virtual } \\
\text { laboratory } \\
\text { environment }\end{array}$ & $\begin{array}{l}\text { Supplement } \\
(1 \text { module })\end{array}$ & $\begin{array}{l}6 \text { undergraduate } \\
\text { students }\end{array}$ & Survey & $\begin{array}{l}\text { No significant } \\
\text { differences in ratings }\end{array}$ \\
Henson, A. ${ }^{62}$ & $\begin{array}{l}\text { Virtual } \\
\text { laboratory } \\
\text { environment }\end{array}$ & $\begin{array}{l}\text { Supplement } \\
(5 \text { modules })\end{array}$ & $\begin{array}{l}37 \text { undergraduate } \\
\text { students }\end{array}$ & $\begin{array}{l}\text { Pre/post-test \& } \\
\text { survey }\end{array}$ & $\begin{array}{l}\text { Students using the } \\
\text { modules performed } \\
\text { higher on post quizzes }\end{array}$ \\
Ogot, M. ${ }^{63}$ & $\begin{array}{l}\text { Replaced }(1 \\
\text { laboratory }\end{array}$ & $\begin{array}{l}35 \text { undergraduate } \\
\text { students }\end{array}$ & $\begin{array}{l}\text { Survey \& } \\
\text { performance } \\
\text { data (report } \\
\text { grade) }\end{array}$ & $\begin{array}{l}\text { No significant } \\
\text { performance } \\
\text { differences; mixed } \\
\text { results for student } \\
\text { comments }\end{array}$
\end{tabular}




\begin{tabular}{llllll} 
Olinger, D. $^{64}$ & $\begin{array}{l}\text { Remote data } \\
\text { acquisition }\end{array}$ & $\begin{array}{l}\text { Supplement } \\
(3 \text { modules })\end{array}$ & $\begin{array}{l}\text { Undergraduate } \\
\text { students }(390 \text { over } \\
3 \text { years })\end{array}$ & Survey & Positive comments \\
Gurocak, H. ${ }^{65}$ & $\begin{array}{l}\text { Remote } \\
\text { laboratory }\end{array}$ & $\begin{array}{l}\text { Replaced (5 } \\
\text { experiments) }\end{array}$ & $\begin{array}{l}\text { Undergraduate } \\
\text { students }(33 \text { total } \\
\text { over 2 terms at } 4 \\
\text { locations })\end{array}$ & $\begin{array}{l}\text { Survey \& } \\
\text { performance } \\
\text { data (final } \\
\text { grades) }\end{array}$ & $\begin{array}{l}\text { No significant } \\
\text { performance } \\
\text { differences; positive } \\
\text { comments }\end{array}$ \\
\hline
\end{tabular}

Students who consistently used virtual laboratory modules performed significantly higher on their post-test scores than students who did not ${ }^{62}$. All students, regardless of their level of usage, gave positive ratings for the course. In a distance-learning laboratory, students rated the effectiveness of the course similarly to students who completed the traditional version of the same course $^{61}$. However, this survey instrument did not specifically address the virtual experiments but rather focused more on the course as a whole.

For remote laboratories, no significant performance differences were found in any of the three articles $^{63-65}$. However, Ogot et al. ${ }^{63}$ reported that although the experimental group had significantly less confidence in the data collected, they were less concerned about making mistakes in the laboratory.

Collectively, these results provide some evidence that laboratories can be offered either virtually or remotely with no negative impact on student learning. Future research should focus on investigating the effect of replacing the traditional laboratory format rather than supplementing it with the virtual or remotely operated formats.

\section{Discussion and Conclusions}

The rationale for this study was to provide an overview of cyberlearning environments within the context of engineering education. The following general conclusions can be made:

1. Each of the articles that were analyzed provides a good base for how individual technologies work and behave as pedagogical tools.

2. The nature of cyberlearning research as evidenced from the publications in the Journal of Engineering Education (JEE) appears to be fairly disjointed. Most articles did not cite other articles researching the same thematic group published in the journal.

3. In most cases, the studies appear to be small in scope, were not longitudinal, and included less than 100 subjects per term. Very few studies were carried out over the course of several terms.

4. There are no published studies in JEE that include more advanced cyber-environments such as the nanoHUB, NEES, or LEAD. Clearly, these advanced cyber-environments are used extensively for teaching and learning. Therefore, we identify a significant area of research that could use environments such as the nanoHUB as an anchor to develop fullfledged theoretical learning frameworks.

5. Research data within the field of engineering education is extremely fragmented and distributed. This finding lays the groundwork for utilizing cyberinfrastructure more effectively for preserving research data within the field of engineering education research. 
6. Finally, despite all the tremendous works that have been published, there is no major new theory or expansions of extant theories to include cyberinfrastructure (or more broadly technology) at the core of the pedagogical framework.

Our future research goals involve expanding this analysis to include several other prominent journals in the field of engineering education. We believe a complete summary can serve to provide a theoretical framework and consistent assessment methods.

\section{Acknowledgment}

This work is supported by National Science Foundation Grant EEC-0747795.

\section{Bibliography}

1. Fouger, X., R. Almgren, K. Gopalakrishnan, P. Mailhot. 2008. Perspectives from industry. Journal of Engineering Education 97 (3): 241-44.

2. Special Report. 2006. The research agenda for the new discipline of engineering education. Journal of Engineering Education 95 (4): 259-261.

3. Katehi, L. and M. Ross. 2007. Technology and culture: Exploring the creative instinct through cultural interpretations. Journal of Engineering Education 96 (2): 89-90.

4. Vest, C. 2008. Context and challenge for twenty-first century engineering education. Journal of Engineering Education 97 (3): 235-36.

5. Fromm, E. 2003. The changing engineering educational paradigm. Journal of Engineering Education 92 (2): 113-21.

6. Dym, C.L., A.M. Agogino, O. Eris, D.D. Frey, and L.J. Leifer. 2005. Engineering design thinking, teaching, and learning. Journal of Engineering Education 94 (1): 103-20.

7. National Academy of Engineering. 2004. The Engineer of 2020. http://books.nap.edu/catalog.php?record id=10999 (accessed February 3, 2009).

8. Bourne, J., D. Harris, and F. Mayadas. 2005. Online engineering education: Learning anywhere, anytime. Journal of Engineering Education 94 (1): 131-46.

9. Barnes, F.S. 2004. Some frontiers for engineering education. Journal of Engineering Education 93(3): 183184.

10. Oblinger, D.G., and J.L. Oblinger. 2005. Is it age or IT: First steps toward understanding the net generation. In Educating the net generation, eds. D.G. Oblinger and J.L. Oblinger, 2.1-2.20. Boulder, CO: EduCause.

11. Chubin, D., K. Donaldson, B. Olds, and L. Fleming. 2008. Educating Generation Net-Can U.S. engineering woo and win the competition for talent? Journal of Engineering Education 97(3): 245-257.

12. Salaway, G., J.B. Caruso, M.R. Nelson, and N. Ellison. 2008. The ECAR Study of Undergraduate Students and Information Technology, 2008. Volume 8. http://connect.educause.edu/library/ERS0808 (accessed March 12, 2009).

13. Jones, S. and S. Fox. 2009. Generations Online in 2009. Pew Internet \& American Life Project. http://www.pewinternet.org/pdfs/PIP Generations 2009.pdf (accessed March 12, 2009).

14. Kadiyala, M. and B.L. Crynes. 2000. A review of the literature on effectiveness of use of information technology in education. Journal of Engineering Education 89 (2): 177-189.

15. Atkins, D.E., K.K. Droegemeier, S.I. Feldman, H. Garcia-Molina, M.L. Klein, D.G. Messerschmitt, P. Messina, J.P. Ostriker, and M.H. Wright. 2003. Revolutionizing Science and Engineering through Cyberinfrastructure: Report of the National Science Foundation blue ribbon advisory panel on cyberinfrastructure. http://www.nsf.gov/od/oci/reports/atkins.pdf (accessed March 12, 2009).

16. Ainsworth, S., M. Honey, W.L. Johnson, K. Koedinger, B. Muramatsu, R. Pea, M. Recker, and S. Weimar. 2005. Cyberinfrastructure for Education and Learning for the Future: A Vision and Research Agenda. http://www.cra.org/reports/cyberinfrastructure.pdf (accessed March 12, 2009). 
17. The National Science Foundation. 2007. Cyberinfrastructure Vision for $21^{\text {st }}$ Century Discovery. http://www.nsf.gov/pubs/2007/nsf0728/nsf0728.pdf accessed (March 12, 2009).

18. Borgman, C.L., H. Abelson, L. Dirks, R. Johnson, K.R. Koedinger, M.C. Linn, C.A. Lynch, D.G. Oblinger, R.D. Pea, K. Salen, M.S. Smith, and A. Szalay. 2008. Fostering Learning in the Networked World: The Cyberlearning Opportunity and Challenge. http://www.nsf.gov/pubs/2008/nsf08204/nsf08204.pdf (accessed March 12, 2009).

19. Tseng, K-H., S-J. Lou, C.R. Diaz, and H-J. Yang. 2006. Using online nominal group technique to implement knowledge transfer. Journal of Engineering Education 95 (4): 335-45.

20. Whitman, L.E., D.E. Malzahn, B.S. Chaparro, M. Russell, R. Langrall, and B.A. Mohler. 2005. A comparison of group processes, performance, and satisfaction in face-to-face versus computer-mediated engineering student design teams. Journal of Engineering Education 94 (3): 327-33.

21. Kirschman, J.S. and J.S. Greenstein. 2002. The use of groupware for collaboration in distributed student engineering design teams. Journal of Engineering Education 91 (4): 403-07.

22. Rutar, T. and G. Mason. 2005. A learning community of university freshman design freshman graphics, and high school technology students: Description, projects, and assessment. Journal of Engineering Education 94 (2): 245-54.

23. Paterson, K.G. 1999. Student perceptions of Internet-based learning tools in environmental engineering education. Journal of Engineering Education 88 (3): 295-304.

24. Liang, T., D.G. Bell, and L.J. Leifer. 2001. Re-use or re-invent? Understanding and supporting learning from experience of peers in a product development community. Journal of Engineering Education 90 (4): $519-26$.

25. Hailey, C.H. and D.E. Hailey. 2003. How genre choices effect learning in a digital environment. Journal of Engineering Education 92 (4): 287-94.

26. Rutz, E., R. Eckart, J.E. Wade, C. Maltbie, C. Rafter, and V. Elkins. 2003. Student performance and acceptance of instructional technology: Comparing technology-enhanced and traditional instruction for a course in statics. Journal of Engineering Education 92 (2): 133-40.

27. Dutton, J., M. Dutton, and J. Perry. 2001. Do online students perform as well as lecture students? Journal of Engineering Education 90 (1): 131-36.

28. Foertsch, J., G. Moses, J. Strikwerda, and M. Litzkow. 2002. Reversing the lecture/homework paradigm using eTEACH ${ }^{\circledR}$ Web-based streaming video software. Journal of Engineering Education 91 (3): 267-74.

29. Haag, S., and J.C. Palais. 2002. Engineering online: Assessing innovative education. Journal of Engineering Education 91 (3): 285-90.

30. Webster, T.J. and K.M. Haberstroh. 2002. An interactive, video-teleconferenced, graduate course in biomedical engineering. Journal of Engineering Education 91 (2): 159-66.

31. Thiagarajan, G. and C. Jacobs. 2001. Teaching undergraduate mechanics via distance learning: A new experience. Journal of Engineering Education 90 (1): 151-56.

32. Evans, R.M., S.L. Murray, M. Daily, and R. Hall. 2000. Effectiveness of an Internet-based graduate engineering management course. Journal of Engineering Education 89 (1): 63-71.

33. Rafe, G. and J.H. Manley. 1999. Assessing quality issues in interactive video teleconferencing-based graduate level engineering courses. Journal of Engineering Education 88 (1): 119-28.

34. Roselli, R.J. and S.P. Brophy. 2006. Experiences with formative assessment in engineering classrooms. Journal of Engineering Education 95 (4): 325-33.

35. Doolen, T.L., J.D. Porter, and J. Hoag. 2003. The relationship between PDA usage and student performance in an introductory engineering course. Journal of Engineering Education 92 (3): 263-68.

36. Kolar, R.L., D.A. Sabatini, and L.D. Fink. 2002. Laptops in the classroom: Do they make a difference? Journal of Engineering Education 91 (4): 397-401.

37. Newman, D.J. and A.R. Amir. 2001. Innovative first year aerospace design course at MIT. Journal of Engineering Education 90 (3): 375-81.

38. Taraban, R., E.E. Anderson, M.W. Hayes, and M.P. Sharma. 2005. Developing on-line homework for introductory thermodynamics. Journal of Engineering Education 94 (3): 339-42.

39. Taraban, R., M.W. Hayes, E.E. Anderson, and M.P. Sharma. 2004. Giving students time for the academic resources that work. Journal of Engineering Education 93 (3): 205-10.

40. Marks, B. 2002. Web-based readiness assessment quizzes. Journal of Engineering Education 91 (1): 97102.

41. Roselli, R.J. and S.P. Brophy. 2006. Effectiveness of challenge-based instruction in biomechanics. Journal of Engineering Education 95 (4): 311-24. 
42. Rayne, K., T. Martin, S. Brophy, N.J. Kemp, J.D. Hart, and K.R. Diller. 2006. The development of adaptive expertise in biomedical engineering ethics. Journal of Engineering Education 95 (2): 165-73.

43. Pandy, M.G., A.J. Petrosino, B.A. Austin, and R.E. Barr. 2004. Assessing adaptive expertise in undergraduate biomechanics. Journal of Engineering Education 93 (3): 211-22.

44. Greenberg, J.E., N.T. Smith, and J.H. Newman. 2003. Instruction module in fourier spectral analysis, based on principles of "How People Learn". Journal of Engineering Education 92 (2): 155-65.

45. Hadjileontiadou, S.J., H.N. Sakonidis, and G.J. Balafoutas. 2003. Lin2k: A novel Web-based collaborative tool-application to engineering education. Journal of Engineering Education 92 (4): 313-324.

46. Nguyen, J. and C.B. Paschal. 2002. Development of an online ultrasound instructional module and comparison to traditional teaching methods. Journal of Engineering Education 91 (3): 275-83.

47. Masten, S.J., K-C. Chen, J. Graulau, S.L. Kari, and K-H. Lee. 2002. A Web-based and group learning environment for introductory environmental engineering. Journal of Engineering Education 91 (1): 69-80.

48. Kashy, D.A., G. Albertelli, E. Kashy, and M. Thoennessen. 2001. Teaching with ALN technology: Benefits and costs. Journal of Engineering Education 90 (4): 499-505.

49. Dorneich, M.C. and P.M. Jones. 2001. The UIUC virtual spectrometer: A Java-based collaborative learning environment. Journal of Engineering Education 90 (4): 713-720.

50. Kortemeyer, G. and W. Bauer. 1999. Multimedia collaborative content creation ( $\left.\mathrm{mc}^{3}\right)$ : The MSU LectureOnline system. Journal of Engineering Education 88 (4): 421-27.

51. Butz, B.P., "The Learning Mechanism of the Interactive Multimedia Intelligent Tutoring System (IMITS)," Journal of Engineering Education, Vol. 90, No. 4, 2001, pp. 543-548.

52. Dearholt, D.W., K.J. Alt, R.F. Halpin, and R.L. Oliver. 2004. Foundational aspects of student-controlled learning: A paradigm for design, development, and assessment appropriate for Web-based instruction. Journal of Engineering Education 93 (2): 129-38.

53. Hsieh, S-J. and P.Y. Hsieh. 2004. Integrated virtual learning system for programmable logic controller. Journal of Engineering Education 93 (2): 169-78.

54. Cantrell, P., G. Pekcan, A. Itani, N.Velasquez-Bryant. 2006. The effects of engineering modules on student learning in middle school science classrooms. Journal of Engineering Education 95 (4): 301-09.

55. Diefes-Dux, H.A., C. Samant, T.E. Johnson, and D. O’Connor. 2004. Kirkpatrick's level 1 evaluation of the implementation of a computer-aided process design tool in a senior-level engineering course. Journal of Engineering Education 93 (4): 321-31.

56. McKenna, A.F. and A.M. Agogino. 2004. Supporting mechanical reasoning with a representationally-rich learning environment. Journal of Engineering Education 93 (2): 97-104.

57. Ressler, S.J. and E.K. Ressler. 2004. Using a nationwide Internet-based bridge design contest as a vehicle for engineering outreach. Journal of Engineering Education 93 (2): 117-28.

58. Mohtar, R.H. and B.A. Engel. 2000. WWW-based water quality modeling systems to enhance student learning. Journal of Engineering Education 89 (1): 89-94.

59. Panetta, K., C. Dornbush, and C. Loomis. 2002. A collaborative learning methodology for enhanced comprehension using TEAMThink ${ }^{\circledR}$. Journal of Engineering Education 91 (2): 223-29.

60. Crown, S.W. 2001. Improving visualization skills of engineering graphics students using simple JavaScript Web-based games. Journal of Engineering Education 90 (3): 347-55.

61. Alexander, D.G. and R.E. Smelser. 2003. Delivering an engineering laboratory course using the Internet, the post office, and a campus visit. Journal of Engineering Education 92 (1): 79-84.

62. Henson, A.B., K.J. Fridley, D.G. Pollock, and C.J. Brahler. 2002. Efficacy of interactive Internet-based education in structural timber design. Journal of Engineering Education 91 (4): 371-78.

63. Ogot, M., G. Elliott, and N. Glumac. 2003. An assessment of in-person and remotely operated laboratories. Journal of Engineering Education 92 (1): 57-64.

64. Olinger, D.J. and J.C. Hermanson. 2002. Integrated thermal-fluid experiments in WPI's discovery classroom. Journal of Engineering Education 91 (2): 239-43.

65. Gurocak, H. 2001. e-Lab: An electronic classroom for real-time distance delivery of a laboratory course. Journal of Engineering Education 90 (4): 695-705. 